\title{
THE PROSPECT OF USING SMART DUSTBIN FOR REDUCING GARBAGE PICK UP TIME (A SIMULATION IN PADANG CITY)
}

\author{
M.Y. Baihaqi ${ }^{1}$, W. Wijaya ${ }^{2}$, M. A. R. Widyoko ${ }^{3}$ and T. Wikaningrum ${ }^{4}$ \\ Faculty of Engineering President University \\ Jl. Ki Hajar Dewantara, Jababeka Education Park, Cikarang, Jawa Barat 17550 \\ 1'yezatoishida0@ gmail.com, ${ }^{2}$ wilbertselamat@ gmail.com, ${ }^{3}$ arwinrnrdi@yahoo.com, ${ }^{4}$ temmy@ president.ac.id
}

\begin{abstract}
Service on garbage pick-up is an obligatory service which, should be provided by the government. Due to human's active mobility, which doing activities that may result in waste, that may cause bad impact on the environment and also human themselves. However, the service cost for garbage pick up is not that affordable, in which government is required to do efficiency, especially to efficient in terms of time. In this study, the place that was used as sample is Padang City. In Padang City, the time that needed to pick-up the garbage from the time the trucks start the trip from the shelter, up to each pick-up point and drop it to the landfill site takes around 6.97 hours (Komala et al.,2012). This data is a secondary data that obtained by previous researchers. In this study, the time simulation has been elaborated by replacing the conventional garbage bin to smart dustbin. Smart dustbin is equipped with sensor to count how much garbage inside it and other types of sensor are also equipped to accommodate its work. In addition, Smart Dustbin also equipped with GSM module to send information for indicating that the garbage bin was full. A simulation result showed that using smart dustbin can reducing the pick-up time according to the pick-up points that informed by the GSM module.
\end{abstract}

Keywords: garbage, simulation, smart dustbin, trash

\begin{abstract}
Abstrak: Pelayanan pengangkutan sampah merupakan pelayanan wajib yang disediakan oleh pemerintah. Hal ini dikarenakan manusia merupakan mahluk yang aktif dalam melakukan kegiatan yangmenghasilkan hasil sisa yang disebut sampah yang tentunya dapat menimbulkan dapat buruk bagi lingkungan maupun manusia itu sendiri. Namun, biaya pelayanan pengangkutan sampah tidaklah murah sehingga pemerintah dituntut untuk melakukan efisiensi, khusunya efisiensi waktu. Pada kajian ini daerah sampel yang digunakan adalah Kota Padang. Di Kota Padang, waktu yang dibutuhkan untuk melakukan pengangkutan sampah dari keluarnya truk dari pool, bongkar muat di tiap titik pengangkutan sampah hingga penurunan sampah di TPA ialah 6.97 jam (Komala et al.,2012). Data ini merupakan data sekunder peneliti lain sebelumnya Pada kajian ini dilakukan simulasi efisiensi waktu dalam pengangkutan sampah dengan menggunakan tong sampah pintar atau smart dustbin sebagai ganti dari tong sampah konvensional. Smart dustbin ini memiliki sensor untuk mengetahui jumlah sampah yang mengisi tong sampah dan sensor lainnya. Smart dustbin juga dilengkapi dengan modul GSM untuk mengirim informasi apabila jumlah sampah telah memenuhi tong sampah. Hasil simulasi menunjukkan bahwa penggunaan smart dustbin dapat menurunkan waktu pengambilan sampah karena pengambilan sampah hanya dilakukan pada tong sampah yang telah penuh sesuai dengan informasi GSM modul
\end{abstract}

Kata Kunci: limbah, sampah, simulasi, bak sampah pintar

\section{INTRODUCTION}

Naturally, human is a productive and active being on doing various action for certain purposes (Yaqin, 2015). However, while doing activities, human often left out trash, especially domestic waste that classified as garbage. Garbage is the refuse which comes from the bathroom and kitchen. It is basically organic waste, clothing, food waste, food containers, paper products etc. Trash is the waste which comes from anywhere but the bathroom and kitchen. It could be old furniture, leaves, twigs, grass clippings, junk and other products which might come under the category of hazardous household waste. In addition, domestic waste is the waste that is produced from human daily activities (Damanhuri and Padmi, 2010). For instance, cardboard, plastic bag, and food can are called domestic waste.

Service on domestic waste pick-up is an obligatory service that must be provided by government for every citizen. According to Li et al. (2006) trash pick-up is the most expensive obligatory service 
that need to be provided by government. Surprisingly, waste pick-up takes up 85\% of the government's total budget on waste management (Apaydin and Gonulu, 2007). By considering that issue, government is forced to have good management system and decent equipment, for the sake of budget effectiveness and efficiency.

According to the Decree of the Ministry of Residential and Regional Infrastructure No.534/KPTS/M/2001, the lowest standard capacity for trash pick-up vehicle is $6 \mathrm{~m}^{3}$. From the statement above, can be concluded that the majority vehicle that are used in Indonesia is trucks. The usage of trucks is considered to be the suitable solution for garbage pick-up due to its higher volume capacity compare to other types of land vehicles. In terms of application, the usage of truck is efficient, when the distance and time duration taken from the shelter to the landfill site can be minimized.

In Indonesia, the pick-up of garbage is done by the garbage truck once in a day up to once in three day. For instance, the garbage pick-up in Padang City is done every day (Komala et al., 2012). The other example is the picking up garbage time in Jabungan, Semarang is once in two days (Cicilia et al., 2017). The frequency of pick-up is determined by calculation, which is based on total pick-up time, loading and unloading the container time, container landing time, distance from shelter to landfill site, and the velocity of truck when fully-loaded and when its unloaded.

Nonetheless, in reality, amount of domestic waste that are produced daily by every citizen is vary from one another. A research of a case, that is conducted by Corio Waste Management, Australia, found that, trash pick-up scheduling system is ineffective (Gale, P., 2017). This thing is also supported by Ridha et al. (2016), the study showed that one of the biggest problem in picking up a domestic waste is ineffective time. This is caused by the amount of domestic waste / garbage produced by citizen especially during weekends and weekdays is different. Besides that, scheduled garbage pick-up is also risky. While, scheduled pick-up is conducted, the officers did not acknowledge the amount of garbage inside the bin, before reaching pick-up point. When they arrived at the pick-up point, there are two possibility, such as the garbage had been overloaded and scattered or there are only few trashes in it. Both of this possibility, may cause disadvantage for the citizen and the garbage pick-up officers.

According to the problem that stated above, it was intended to seek opportunity for increasing the effectiveness of garbage pick-up. The study was elaborate the opportunity to use smart dustbin and comparison between the usage of smart dustbin vs the scheduled pick-up. For, regional restriction, the projection on this research is using Padang City as the sample. With the route that will be pass by from shelter -By Pass street - Samarinda street - Belawan I street- Belawan II street- Belawan III street- Banjarmasin street- By Pass street - Lb. Minturun street- Air Dingin landfill site (Komala et al., 2012).

Referring to research that was conducted by Monika et al. (2016), the definition of smart dustbin is the garbage bin that equipped with ultrasonic sensor as the detector of the volume of in the bin. Sensor is a device that can be used for sensing surroundings, which also can be used to send and collect information onto other devices under certain conditions (Jazar, 2010). Inside the ultrasonic sensor, piezoelectric component present as component to trigger the sound wave. The common frequency that is emitted from piezoelectric is $40 \mathrm{kHz}$ (Satoto et al., 2017). Then, the sound wave is reflected perpendicularly by the soft material in front (Borenstein dan Koren, 2014). Figure 1 is the Picture of Ultrasonic Sensor. In addition, garbage bin need to send the reading through a media. The media can 
be SMS or internet connection. Monika et al. (2016) used GSM module to send message whenever the garbage bin is full. Completing the reference GSM module is defined as module that can be integrated with sim card that operates by subscription to the cellular operator (Eseosa \& Promise, 2014).

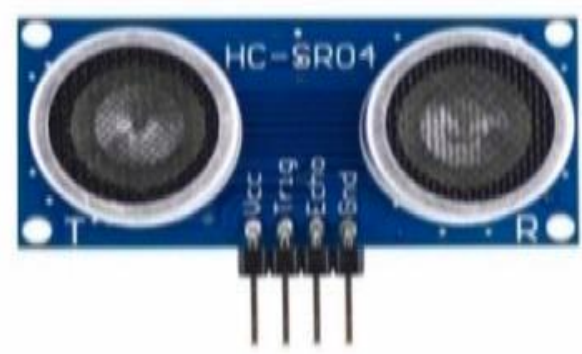

Figure 1. Ultrasonic Sensor (source : Satoto et al., 2017)

Up to now, GSM module operates on $900 \mathrm{MHz}$ frequency (Fauzi et al, 2017). GSM module can operate either as the acceptor (message sender) or the receptor (message recipient) (Gupta, 2015). In this study the GSM module that is installed on the smart dustbin will act as the message sender, especially when the garbage bin is full. Figure 2 is the picture of GSM Module.

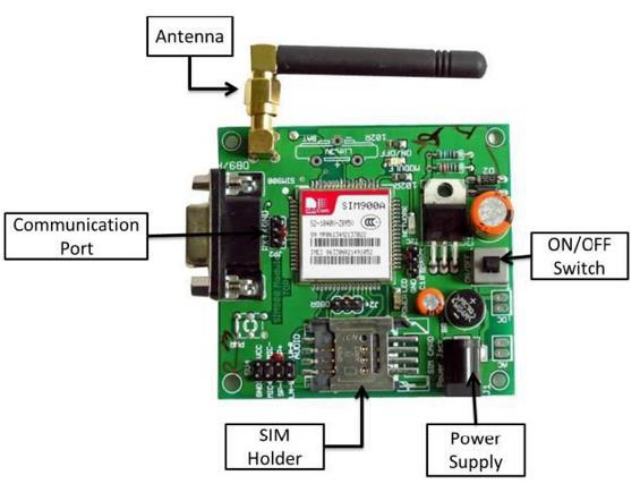

Figure 2.GSM Module (source : Nagaraju et al., 2017)

In research of Monika et al. (2016), the smart dustbin could not be applied on outdoor environment, due to its requirement for power source from serial port of the microcontroller (Figure 3)

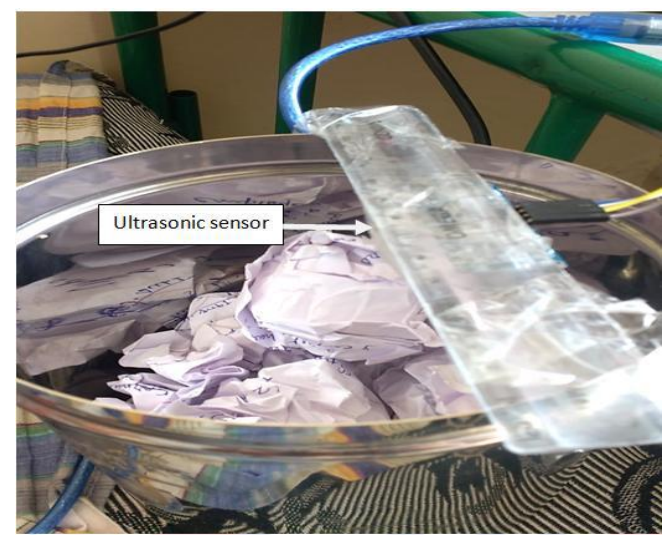

Figure 3. Smart trash bin made by Monika et al.(2016)

Samann (2017) designed and implement smart dustbin as the replacement of trash bin that can be used outdoors. Smart dustbin that made by Samann has higher specifications and more feature compare to smart dustbin made by Monika et al (2016). Figure 4, showing the physical appearance of smart dustbin made by Samann (2017)

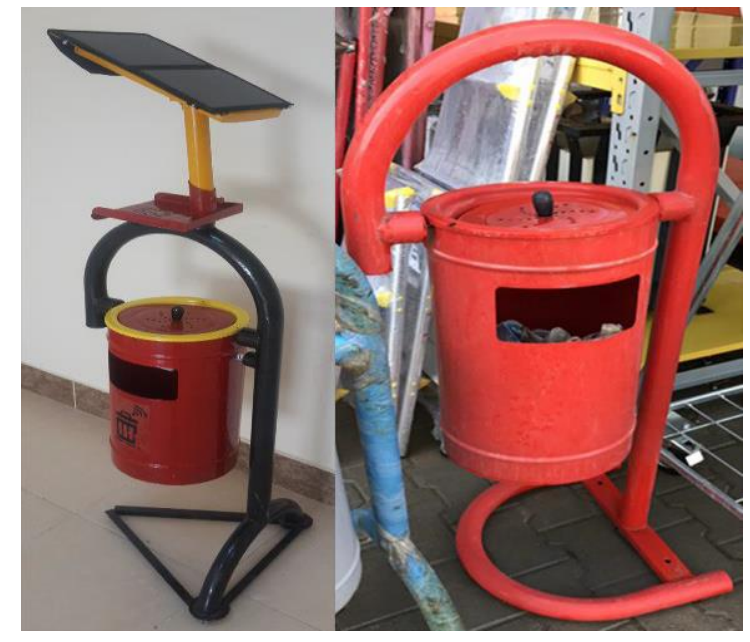

Figure 4. Smart dustbin made by Samann (2017).

Samann (2017) has solved the problem on power source by using solar panel and has successfully made smart dustbin that can be used in outdoor environment. PIR (passive infrared sensor) that is used here serves as the trash bin opener which detect the existence of hand gesture waiving 
around trash bin. PIR sensor works by detecting the infrared radiation that is emitted by human body (Chodon et al, 2013).The usage of PIR sensor is considered to be appropriate, since it can operates under low power (Yun \& Lee, 2014). In addition, PIR sensor can perform up to $180^{\circ}$ reading (Kumar et al, 2015). Figure 5 is the picture of PIR sensor.

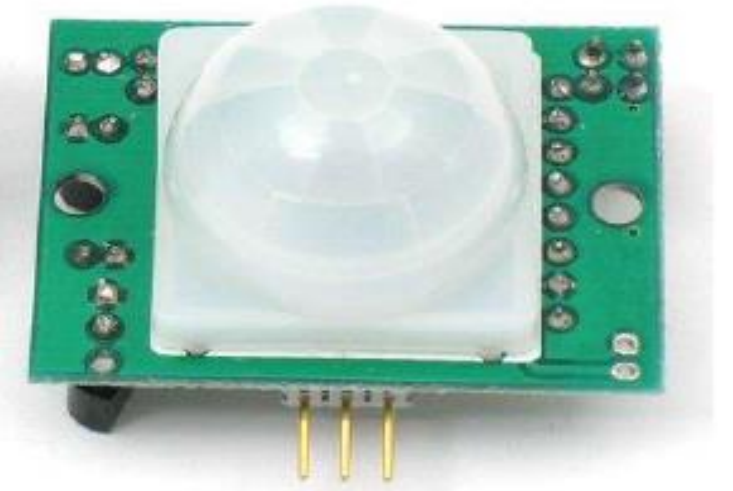

Figure 5. PIR Sensor (source : Kumar et al., 2015)

In other words, smart trash bin that used in this study is garbage bin that equipped with sensor and has the ability to send information to the responsible party to pick-up the garbage. Sensor that is used in the bins are ultrasonic sensor and PIR sensor, in which ultrasonic sensor serve as the load detector of trash bin, and PIR sensor to sense the handwaving gesture around the smart bin, so that the smart bin will automatically open. Having equipped with GSM Module, which has the ability to send information through SMS, smart dustbin will directly send the information to the party who is responsible for pick-up the trash, when the trash bin is full and its real-time. Considering all of the justification above, the objective of this study is elaborating the opportunity of using smart bin for increasing time management efficiency in the garbage pick up time.

\section{MATERIAL AND METHODS}

The secondary data of scheduled garbage pick-up in Padang City, used in this study is taken from the previous research conducted by Koamal et al. (2012). The used data were : route, distance, and pickup time in every stop. The component of data for garbage pick-up are elaborated on Table 1.

Table 1. Garbage pick-up time component (Komala et al., 2012)

\begin{tabular}{|c|c|c|c|c|}
\hline No & Description & $\begin{array}{c}\text { Value } \\
\text { (hrs) }\end{array}$ & Times & $\begin{array}{c}\text { Total } \\
\text { (hrs) }\end{array}$ \\
\hline 1 & $\begin{array}{l}\text { Duration } \\
\text { from } \\
\text { shelter to } \\
\text { landfill site }\end{array}$ & 3.9 & 1 & 3.9 \\
\hline 2 & $\begin{array}{c}\text { Loading } \\
\text { and } \\
\text { unloading } \\
\text { time }\end{array}$ & 0.36 & 8 & 2.88 \\
\hline 3 & $\begin{array}{c}\text { Time taken } \\
\text { for } \\
\text { dropping } \\
\text { trash from } \\
\text { truck to } \\
\text { Landfill }\end{array}$ & 0.19 & 1 & 0.19 \\
\hline & Total & & 6.97 \\
\hline
\end{tabular}

Route that used were, Shelter - By Pass street - Samarinda street - Belawan I street - Belawan II street - Belawan III street - Banjarmasin street - By Pass street - Lb. Minturun street -Air Dingin landfill site. The following route were the route pass by the garbage truck to reach Air Dingin landfill site. This route has 8 stop points for garbage pick-up. This $45 \mathrm{~km}$ long route is freeway and non-turning one. Figure 6 shows the route that will be passed by garbage truck.

By referring to the data, the study was made a simulation if the garbage is taken by time scheduled pick-up as existing and compare to when using smart trash bin. The simulation is to elaborate the opportunity for reducing pick up time due by using smart bin that can be operated real-time. The device can give the information of number of smart bin that 
already have fill up, therefore when the trash bin haven't full yet, the garbage pickup officer won't have to stop by to do the pick-up process. On the other hand, by having shorter duration or reduced time on pick-up process may result in more efficient fuel consumption of the truck.

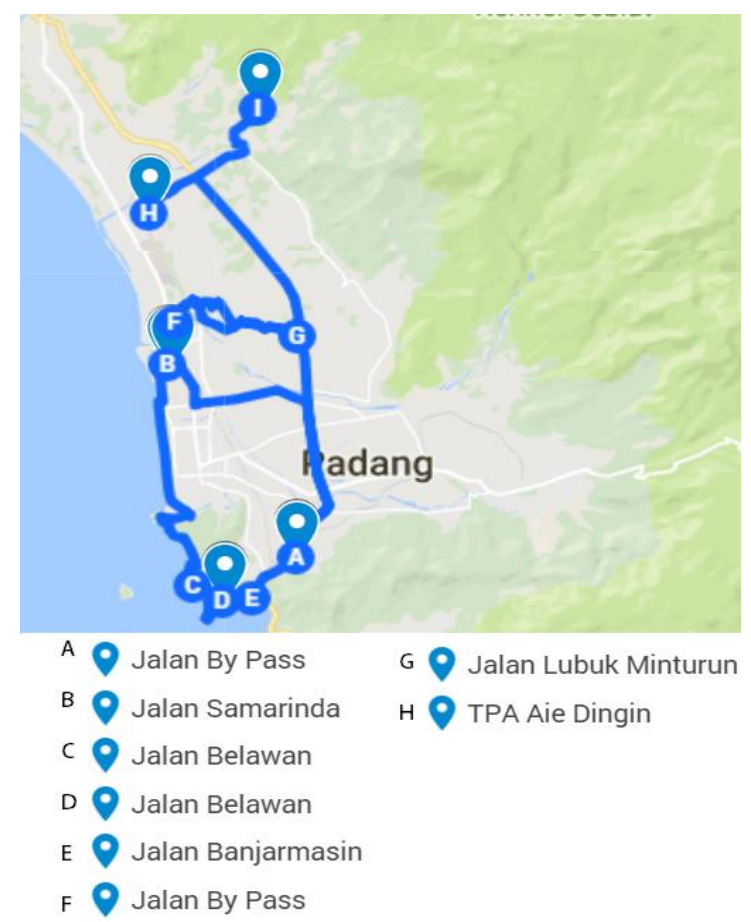

Figure 6. Garbage truck pick-up route

\section{RESULT AND DISCUSSION}

Referring to the data on Table 1, the travel duration from the shelter up to landfill site needs 3.9 hours or 3 hours and 54 minutes. Then, the loading and unloading time per pick-up point is 0.36 hours. In which, the time taken for 8 pick-up point is 2.88 hours.On the other hand, the time that required to drop the trash from the truck to landfill site is 0.19 hours. In other words, can be concluded that the time-taken from the shelter to pick-up trash on 8 pick-up point and drop all the trash from the truck to the landfill site is 6.97 hours.

With total time spent 6.97 hours of picking-up and stop at the points where no acknowledgement of whether the trash bin is empty or fully loaded. The other possibility is that, they came late and the trash may have been scattered around that area. By using smart dustbin, the garbage pick-up officer does not need to worry about the scattering garbage, with the aid of ultrasonic sensor that will lock the smart bin when it is fully loaded. Besides that, when the smart bin is full it will send message to do the pick-up and whenever they do not get any messages from the smart bin, they don't need to stop for checking the smart bin, when its not fully load yet, which is considered to be ineffective act. In other words, the pick-up time can be shorter, fuel consumption and labour cost can more efficient compare to scheduled pick-up. Table 2. Shows the time-taken when using smart dustbin.

Tabel 2. Total time-taken for picking-up using smart dustbin (source : data simulation)

\begin{tabular}{|c|c|}
\hline $\begin{array}{c}\text { Total pick-up } \\
\text { points (times) }\end{array}$ & Total time-taken (hrs) \\
\hline 1 & 4.45 \\
\hline 2 & 4.81 \\
\hline 3 & 5.17 \\
\hline 4 & 5.53 \\
\hline 5 & 5.89 \\
\hline 6 & 6.25 \\
\hline 7 & 6.61 \\
\hline 8 & 6.97 \\
\hline
\end{tabular}

Table 2. shows total time-taken for picking-up using smart dustbin. As stated in the previous paragraph, that smart dustbin will give information real-time, on the volume of trash that filled up the trash bin. On table 2., also shows the total time taken for trash pick-up for one up to eight points that filled up the trash bin. For instance, when there is only four pick-up point to stop by for trash pick-up it only requires 5.53 hours from shelter going to the four stop points and moving the trash from the truck to the landfill site. The calculation for simulation with data from Table 1 is $3.9+(4 \times 0.36))+0.19=5.53$ 
hours. This pick-up time can not be obtained when smart dustbin is not applied, due to the stops made by the truck to check it sequentially. In addition, Figure 7 shows the graph of total timetaken versus the number of pick-up points.

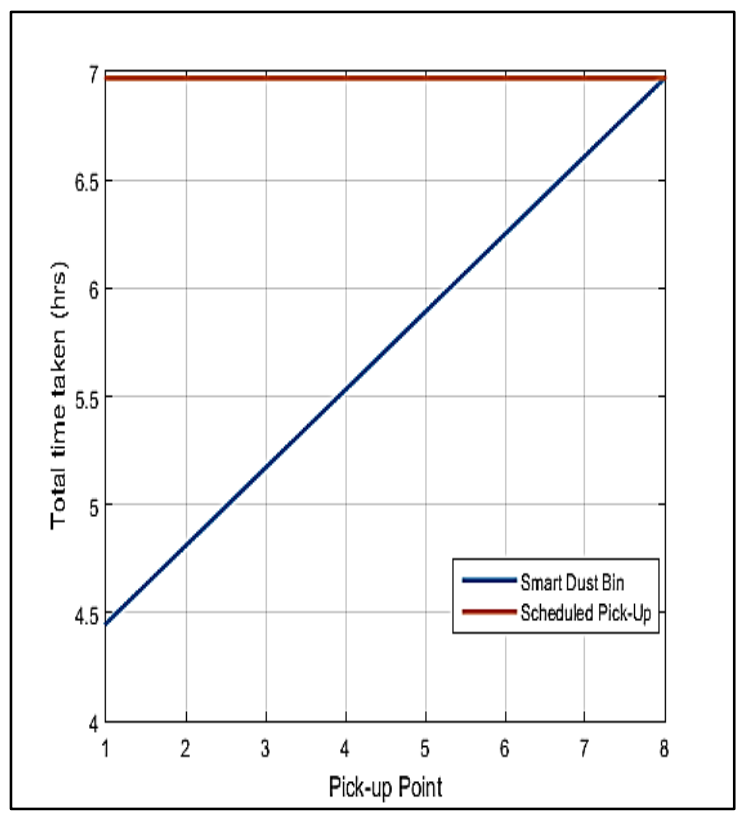

Figure 7. Graph of waktu total time-taken - Pickup points

(source : data simulation)

Figure 7 shows the comparison between the total time-taken using scheduled pickup and smart dustbin as the pick-up basis. On Scheduled pick-up total time-taken is not determined by the total pick-up points. It is caused by the scheduled pick-up can not determine the number of trash in every pick-up points. Therefore, the trash pickup truck should stop by and do the checking procedure.

On the other hand, pick-up using the smart dustbin, which can send information on the amount of trash that has been accumulated on the trash bin. In which, when the existing trash did not fill up the trash bin yet, the officers did not need to stop and do the checking procedure. By using smart dustbin, can save up 0.36 hours per pick-up point.
On the pick-up using smart dustbin can be seen that the time-taken is proportional to the number of pick-up point. In other words, the less number of pick-up point then the shorter time it takes and vice versa.

\section{CONCLUSION}

The time management in picking up of the City's garbage was studied by implementing smart dustbin. The simulation route and time were using secondary data of Padang City. The smart dustbin that recommended in this study is that equiped by solar panel for energy source, PIR (passive infra red) for open / close the bin, ultrasonic sensor for detecting the load of bin, and also GSM module to send message the officer. By simulation that only for full dustbin the officer will stop by, the picking points will be reduced. Reducing picking up points means reducing serve time, fuel and labour cost and other cost This efficiency opportunity may be followed by the next study that include comparison in the investment, operation and maintenance cost, and may also social aspects

\section{ACKNOWLEDGEMENT}

Hereby we would like to thank all of the authors that had published their research paper and journal, that is helpful for completing the study.

\section{REFERENCE}

Apaydin O, dan Gonullu MT, 2007. Route Optimization for solid waste collection: Trabzon (Turkey) Case Study. Global NEST Journal, 9(1), pp. 6-11.

Borenstein J dan Koren Y. 1988. Obstacle avoidance with ultrasonic sensors. IEEE Journal on Robotics and Automation, 4(2), pp.213-218

Chodon P, Adhikari DM, Nepal GC, Biswa, R, Gyeltshen S, and Chencho. 2013. Passive Infrared (PIR) sensor based Security System. 
(IJEECS) International Journal of Electrical, Electronics and Computer Systems ,14(2)

Cicilia K, Samadikun BP, and Handayani DS. 2017. Perencanaan Teknis Pengelolaan Sampah Terpadu : Studi kasus Kelurahan Jabungan, Kecamatan Banyumanik, Kota Semarang. Jurnal Teknik Lingkungan Universitas Diponegoro, 6(1).

Damanhuri E and Padmi T. 2010. Diktat Kuliah Pengolahan Sampah (1st ed.). Bandung: Bandung Institute Technology.

Eseosa O and Promise E. 2014. GSM Based Intelligent Home Security System for Intrusion Detection. International Journal of Engineering and Technology, 4(10), pp. 595-605

Fauzi F, Mahyuddin M and Lahna, K. 2018. Utilization of GSM Module (Sim 900) Based Arduino-Uno for Alarm System and Remote Automatic Door Locking. Journal Of Aceh Physics Society, 7(1), pp.35-38.

Gale, P. 2016. SmartBin Revolutionising Waste Management in Australia. Retrieved from https://www.smartbin.com/australias-coriowaste-management-discuss-implementingsmartbin/.

Gupta, A. 2015. Intelligent Home security using GSM communication module. International Journal of Innovation and Scientific Research, 13(1), pp. 239-242

Jazar, R. 2010. Theory of applied robotics. New York: Springer.

Kumar KS , Priscilla P, Jose GK, Balagopal G. 2015. Human Detection Robot using PIR Sensors. International Journal of Science, Engineering and Technology Research (IJSETR), 4(3), pp. 492-496

Komala P, Aziz R dan Ramadhani F. 2012. Productivity Analysis of Municipal Waste Transportation System in Padang City. Jurnal Teknik Lingkungan UNAND 9, 9(2), pp. 95-109.

Li JQ, Borensteinb D, dan Mirchandani PB, Truck scheduling for solidwaste collection in the City of Porto Alegre, Brazil. Omega the International journal of management science. doi:10.1016/j.omega.2006.04.00.

Monika KA, Rao N, Prapulla SB and Shobha G. 2016. Smart Dustbin-An Efficient Garbage Monitoring System International Journal of Engineering Science and Computing 6 7113-16

Nagaraju U et al. 2017. Smart dustbin for economic growth. Research Prject. School of Information Technology and Enginering. VIT University, Vallore. India
Republic of Indonesia. Keputusan Menteri Pemukiman dan Prasarana Wilayah No.534/KPTS/M/2001. Menteri Pemukiman dan Prasarana Wilayah. Jakarta.

Ridha, M., Abdi, C., \& Mahyudin, R. 2016. Studi Optimasi Rute Pengangkutan Sampah Kota Marhaban dengan Sistem Informasi Geografis. Jukung Jurnal Teknik Lingkungan, 2(2), pp.3851 .

Samann FEF. 2017. The Design and Implementation of Smart Trash Bin. Academic Journal of Nawroz University, [S.1.], v.6, n.3, p. 141-148, aug. ISSN 2520-789X. Available at: <https://journals.

nawroz.edu.krd/index.php/ajnu/article/view/103> Date accessed: 25 july 2018. doi: https://doi.org/10.25007/ajnu.v6n3a103

Satoto B, Yasid A Joni K and Khotimah B. 2017. Monitoring Kesehatan Menggunakan Compiler Arduino \& Modul WiFi-ESP8266 untuk Komunitas Pasien Hipertensi.Seminar

Nasional Matematika dan Aplikasiannya 2017. Surabaya: Universitas Airlangga.

Yaqin, M. .2015. Esensi Manusia Produktif. Retrieved from https://www.kompasiana .com/sofiatus/5554811bb67e616b14ba54a9/esen si-manusia-produktif.

Yun J and Lee S. 2014. Human Movement Detection and Identification Using Pyroelectric Infrared Sensors, Sensors, 14(5), pp. 8057-808, https://doi.org/ 10.3390/s140508057 